\title{
Effects of Organic Manures in Changes of Some Soil Properties at Different Incubation Periods
}

\author{
Sajal Roy, Md. Abul Kashem* \\ Department of Soil Science, University of Chittagong, Chittagong, Bangladesh \\ Email: ${ }^{*}$ kashem00@yahoo.com
}

Received 19 January 2014; revised 19 February 2014; accepted 26 February 2014

Copyright (C) 2014 by authors and Scientific Research Publishing Inc.

This work is licensed under the Creative Commons Attribution International License (CC BY). http://creativecommons.org/licenses/by/4.0/

(c) (i) Open Access

\section{Abstract}

A laboratory incubation experiment of 60 days was carried out to observe the changes of soil pH, electrical conductivity (EC), soil organic carbon (SOC), and potassium chloride extractable nitrogen $\left(\mathrm{NH}_{4}^{+}-\mathrm{N}\right)$ in a soil to which three animal manures viz. cow dung (CD), chicken manure (CM) and a combination of CD and CM had been applied at a rate of $10 \mathrm{t} \cdot \mathrm{ha}^{-1}$. The effects of manures varied with manure type and incubation period. Soil pH slightly increased with the incubation period up to 30 days there after it declined with time significantly $(p<0.05)$. There was a significant $(p<$ 0.05 ) increase in EC as days of incubation increased. Organic carbon contents of manure treated soils reached its peak at 15 days of incubation and decreased thereafter with time. The content of $\mathrm{NH}_{4}^{+}-\mathrm{N}$ increased significantly $(\mathrm{p}<0.05)$ as incubation period increased in control and cow dung amended soils whereas there was no significant difference in $\mathrm{NH}_{4}^{+}-\mathrm{N}$ contents when either chicken manure alone or cow dung and chicken manure mixed in combination. After 60 days of incubation, the highest amount of $\mathrm{NH}_{4}^{+}-\mathrm{N}$ was found in cow dung plus chicken manure treated soil followed by chicken manure treatment.

\section{Keywords}

Chicken Manure; Cow Dung; Incubation

\section{Introduction}

The addition of organic materials such as crop residues, animal manures, green manures to soils have a direct *Corresponding author. 
effect on soil organic matter content, can improve soil fertility, soil physical characteristics, and augment microbial activities, can ameliorate metal toxicity, and by complexation [1]-[3]. Soil organic matter undergoes mineralization and releases substantial quantities of nitrogen, phosphorus, sulfur and smaller amount of micronutrients [4]. Animal manure is considered a valuable nutrient source when applied to soil at rates commensurate with good agronomic practices [5]. The quantity of soil organic matter depends on the quantity of organic materials introduced into the soil either by natural returns through roots, stubbles, sloughed-off root nodules and root exudates or by artificial application in the form of organic manures. In recent times, organic manures in conjunction with or as an alternative to chemical fertilizers as a source of plant nutrients for cultivation of field crops has received worldwide attention due to rising costs of chemical fertilizers, rapid nutrient loss of added fertilizers and adverse environmental impacts from inorganic fertilizers. Accumulation of nutrients in soils, particularly nitrogen, phosphorus and several micronutrients increases the potential for the degradation of surface and ground water resources, especially when manure application is nitrogen based [6] [7].

Organic manures have been proven to enhance efficiency and reduce the need for chemical fertilizers, to improve the soil fertility and soil health [8]. The accurate amount of manure could efficiently be calculated from precise measurement of nutrient mineralization without loss of yield and increased risk of environmental pollution. The suitability of organic materials as fertilizer depends to a great extent on its rapidity of mineralization and liberating the nutrients present in them [9]. The mineralization of organic manures in soil is affected by such soil properties as types of soils, depth of soil, temperature, soil moisture, $\mathrm{pH}, \mathrm{C} / \mathrm{N}$ ratio and lignin content [10] [11]. Climatic conditions, particularly warm temperature which is prominent in Bangladesh during most of the year, and frequently excessive soil tillage promote the mineralization of organic materials. To meet crop nutrient requirements, knowledge of soil characteristics following organic manure application is needed. Thus, it is pertinent to observe the some changes in soil properties with time due to manuring. The study was carried out to observe the changes in $\mathrm{pH}$, electrical conductivity, organic carbon content and potassium extractable $\mathrm{NH}_{4}^{+}-\mathrm{N}$ content of soil amended with cow dung, chicken manure and a combination of cow dung and chicken manure in laboratory incubation condition.

\section{Materials and Methods}

The pattern of $\mathrm{pH}$, electrical conductivity, organic carbon content and available $\mathrm{NH}_{4}^{+}-\mathrm{N}$ treated with different sources of organic manures viz. cow dung and chicken manure, and a combination of cow dung and chicken manure was investigated in the artificial incubation chamber at field capacity condition during the period of June to July, 2013 in the Department of Soil Science, University of Chittagong, Bangladesh.

A bulk soil samples from a depth of 0 to $15 \mathrm{~cm}$ was collected from Soil Science research field of the University of Chittagong which belongs to Chittagong Hill Tract. After collection of the soil samples unwanted roots and debris was removed and dried in air for at least 3 days until a constant weight is achieved. After air drying the soil samples was screened by passing through a $2 \mathrm{~mm}$ sieve. Cow dung and chicken manures were collected from local farm. After collection the manures was dried in air for 3 days and sieved through a $2 \mathrm{~mm}$ sieve. Manures were mixed with soil on oven dry weight basis.

An amount of $100 \mathrm{~g}$ air dry soil was weighed and taken in plastic containers $(5 \times 5 \mathrm{~cm})$. The organic manures were thoroughly mixed with soil at a rate of $10 \mathrm{t}^{\cdot h \mathrm{~h}^{-1}}$. Thus the arrangement of the total treatment was:

Control (C): No manure added

Cow dung $\left(10 \mathrm{t} \cdot \mathrm{ha}^{-1}\right)$

Chicken manure $\left(10 \mathrm{t}^{-h a^{-1}}\right)$

Cow dung $\left(5 \mathrm{t} \cdot \mathrm{ha}^{-1}\right)+$ Chicken manure $\left(5 \mathrm{t} \cdot \mathrm{ha}^{-1}\right)$

The soil samples were incubated at room temperature $\left(\sim 30^{\circ} \mathrm{C}\right)$. The moisture of the soil was kept at field capacity condition (34.33\%) by using distilled water. Soil samples were collected periodically at 15, 30, 45 and 60 days of incubation. Soil samples were collected by destructive method. So, a total of 48 plastic containers were used during the whole incubation period $(4 \times 3 \times 4=48)$. Plastic containers were arranged in completely randomized way. The results will be expressed on oven dry weight basis.

At each sampling date soil samples were collected through destructive sampling techniques where whole soil mass was taken. After collection, the samples were air dried and sieved by passing through $2 \mathrm{~mm}$ sieve. These samples were analyzed for the $\mathrm{pH}$, electrical conductivity organic carbon, potassium chloride extractable $\mathrm{NH}_{4}^{+}-\mathrm{N}$. pH of organic manures and soil was measured by Mettler Toledo $\mathrm{pH}$ meter after preparing the suspen- 
sion at a ratio of 1:10 and 1:2.5 respectively. Electrical conductivity of soil and organic manures was measured in 1:5 and 1:10 suspensions with the help of HANNA 214 conductivity meter. Organic carbon content of soil and organic manures was determined by Walkly and Black oxidation method as followed by Huq and Alam [12]. For the determination of $\mathrm{NH}_{4}^{+}$, the soil samples were extracted with $1 \mathrm{~N} \mathrm{KCl}$ at a ratio of 1:10. Then, $10 \mathrm{ml}$ extract was distilled with $10 \mathrm{ml}$ of $40 \%$ sodium hydroxide using a micro Kjeldahl's distilling unit into an Erlenmeyer flask containing $10 \mathrm{ml}$ boric acid-mixed indicator solution until about $50 \mathrm{ml}$ distillate in each flask was collected. After distillation, $\mathrm{NH}_{4}^{+}$content was determined in the distillate by titrating with standardized 0.013 $\mathrm{N}$ sulphuric acid [12]. For the determination of total nitrogen in soil and organic manures, the samples were di-

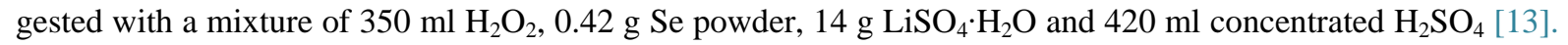
The digestion of a suitable amount $(\sim 0.2 \mathrm{~g})$ of soil and manure samples was performed with 5 ml digestion mixture solution in a digestion block by heating with a starting temperature of $50^{\circ} \mathrm{C}$ that ends to $350^{\circ} \mathrm{C}$ for 6 hours. Data was analyzed by using Microsoft Excel 2010 and SPSS (version 16).

\section{Results and Discussion}

\subsection{Soil pH}

The experimental soil was generally acidic, and had a very low organic matter (Table 1). The pH of chicken manure was slightly acidic, whereas cow dung was found to be slightly alkaline. Organic carbon and total nitrogen content of chicken manure was found higher in comparison to Cow dung (Table 1).

Regardless of amendments, soil pH gradually decreased with the increase of incubation time (Table 2). The trend of soil $\mathrm{pH}$ reduction was similar in all amended soils and the amount of reduction was about 1 unit within 60 days of incubation. The results indicated significant differences in pH between control and organic manure amended soils throughout the incubation period. Dikinya and Mufwanzala [14] observed that the application of chicken manure irrespective of the application rate did not change the $\mathrm{pH}$ of amended soil. Azeez and Van Averbeke [15] reported that $\mathrm{pH}$ of cattle and goat manures are significantly greater than that of poultry manure treatment.

\subsection{Soil EC}

Table 3 shows the electrical conductivity (EC) values of amended and non-amended soils at different incubation periods. Opposite of soil $\mathrm{pH}$, soil EC gradually increased with incubation time significantly and the magnitude of increase was higher in the manure amended soil than the control soil. Combined addition of cow dung and chicken manure resulted in higher EC (33.11\%) than from non-amended (control) soil at the end of the incubation study. At 60 days of incubation, the highest increase of 81.59\% was observed when cow dung and chicken manure applied in combination followed by chicken manure alone (58.88\%) in comparison to soils sampled after 15 days. Electrical conductivity can serve as a measure of soluble nutrients for both cations and anions. Soil EC indicates the mineralization of organic matter in soil and serves as a measure of soluble nutrients [16] [17]. Eigenberg et al. [18] revealed that nitrogen content of soils may be monitored using EC measurements mentioning significant positive relationship. Azeez and Van Averbeke [15] found that electrical conductivity of soil significantly increases with the application of poultry, cattle and goat manures and the potential of manure-induced soil salinization was very high in poultry manure and goat manure compared with cattle manure. Dikinya and Mufwanzala [14] revealed increased electrical conductivity with increasing rates of chicken manures.

\subsection{Soil Organic Carbon Content}

The result indicates that manure application initially increased soil organic carbon content of manure amended soils (Table 4). Organic carbon content was found to be $14.44 \%$ higher in cow dung, $16.82 \%$ in chicken manure and $12.85 \%$ in cow dung plus chicken manure treated soils over the initial value (0.604\%) after 15 days of incubation. In case of control, organic carbon reached its peak at 30 days of incubation and decreased thereafter with time. After 15 days, organic carbon content decreased significantly $(p<0.05$ ) in control and chicken manure treated soils. However, no significant difference was found among different periods of incubation when cow dung alone or cow dung plus chicken manure applied in combination. Organic carbon content of cow dung treated soil was decreased until 45 days and then remained constant during the incubation. At 45 days of incubation, manure additions did not affect soil organic carbon content, while a significant variation $(\mathrm{p}<0.05)$ was found among 
Table 1. Some chemical properties of soil and manures.

\begin{tabular}{cccccc}
\hline Sample & $\mathrm{pH}$ & $\mathrm{OC}(\%)$ & Total N (\%) & $\mathrm{C}: \mathrm{N}$ & $\mathrm{NH}_{4}^{+}\left(\mathrm{mg}^{\circ} \mathrm{kg}^{-1}\right)$ \\
\hline Soil & 5.03 & 0.60 & 0.52 & 1.15 & 88.92 \\
Cow dung & 7.71 & 6.65 & 2.13 & 3.12 & - \\
Chicken manure & 6.76 & 8.96 & 2.74 & 3.27 & - \\
\hline
\end{tabular}

Table 2. pH of soils at different periods of incubation.

\begin{tabular}{|c|c|c|c|c|}
\hline \multirow{2}{*}{ Treatments } & \multicolumn{4}{|c|}{ Periods of Incubation } \\
\hline & 15 days & 30 days & 45 days & 60 days \\
\hline Control & $5.43 a \pm 0.06$ & $5.57 \mathrm{a} \pm 0.04$ & $4.98 b \pm 0.17$ & $4.50 \mathrm{c} \pm 0.08$ \\
\hline CD $\left(10 \mathrm{t} \cdot \mathrm{ha}^{-1}\right)$ & $5.57 a \pm 0.16$ & $5.66 a \pm 0.04$ & $5.07 b \pm 0.06$ & $4.67 \mathrm{c} \pm 0.06$ \\
\hline CM (10 t $\left.\cdot \mathrm{ha}^{-1}\right)$ & $5.76 a \pm 0.11$ & $5.77 a \pm 0.08$ & $5.28 b \pm 0.07$ & $4.73 c \pm 0.02$ \\
\hline CD + CM (1:1) & $5.75 a \pm 0.14$ & $5.74 a \pm 0.11$ & $5.36 b \pm 0.02$ & $4.74 \mathrm{c} \pm 0.10$ \\
\hline
\end{tabular}

Means followed by the same letter(s) in a raw(s) do not differ significantly from each other at 5\% level of significance.

Table 3. Electrical conductivity $\left(\mathrm{mS} \cdot \mathrm{m}^{-1}\right)$ of soils at different periods of incubation.

\begin{tabular}{|c|c|c|c|c|}
\hline \multirow{2}{*}{ Treatments } & \multicolumn{4}{|c|}{ Periods of Incubation } \\
\hline & 15 days & 30 days & 45 days & 60 days \\
\hline Control & $32.7 c \pm 2.75$ & $32.8 \mathrm{c} \pm 1.46$ & $38.4 b \pm 0.95$ & $44.7 \mathrm{a} \pm 2.56$ \\
\hline CD $\left(10 t \cdot h a^{-1}\right)$ & $35.4 b \pm 0.76$ & $38.7 b \pm 2.60$ & $44.9 a \pm 2.73$ & $47.5 a \pm 2.84$ \\
\hline CM $\left(10 \mathrm{t} \cdot \mathrm{ha}^{-1}\right)$ & $35.6 \mathrm{~d} \pm 2.57$ & $40.7 c \pm 0.87$ & $48.2 b \pm 2.54$ & $56.6 \mathrm{a} \pm 2.08$ \\
\hline CD + CM (1:1) & $32.7 d \pm 2.58$ & $37.4 \mathrm{c} \pm 2.23$ & $45.3 b \pm 2.43$ & $59.5 a \pm 0.50$ \\
\hline
\end{tabular}

Means followed by the same letter(s) in a raw(s) do not differ significantly from each other at 5\% level of significance.

Table 4. Organic carbon (OC) contents (\%) of soils at different periods of incubation.

\begin{tabular}{|c|c|c|c|c|}
\hline \multirow{2}{*}{ Treatments } & \multicolumn{4}{|c|}{ Periods of Incubation } \\
\hline & 15 days & 30 days & 45 days & 60 days \\
\hline Control & $0.538 b \pm 0.008$ & $0.590 \mathrm{a} \pm 0.029$ & $0.523 b \pm 0.022$ & $0.514 b \pm 0.008$ \\
\hline CD (10 t $\left.\cdot \mathrm{ha}^{-1}\right)$ & $0.691 \mathrm{a} \pm 0.126$ & $0.662 \mathrm{a} \pm 0.072$ & $0.638 \mathrm{a} \pm 0.008$ & $0.638 a \pm 0.008$ \\
\hline CM (10 t $\left.\cdot h a^{-1}\right)$ & $0.706 \mathrm{a} \pm 0.025$ & $0.672 \mathrm{a} \pm 0.030$ & $0.667 \mathrm{a} \pm 0.046$ & $0.595 b \pm 0.022$ \\
\hline CD + CM (1:1) & $0.682 \mathrm{a} \pm 0.008$ & $0.677 \mathrm{ab} \pm 0.00$ & $0.638 \mathrm{ab} \pm 0.051$ & $0.624 b \pm 0.017$ \\
\hline
\end{tabular}

Means followed by the same letter(s) in a raw(s) do not differ significantly from each other at $5 \%$ level of significance.

treatment during other incubation periods. At the end of the incubation, the maximum decrease of $15.65 \%$ was observed when chicken manure was applied followed by cow dung plus chicken manure (8.45\%) treated soils. The change in organic carbon amount was $4.46 \%$ less in soils where no manure added at 60 days of its first incubation period (15 days). The highest amount of soil organic carbon at the beginning of the incubation was indicative of a larger pool of the less resistant fractions that were available to be broken down and recycled, thus resulting in lower contents remaining at the end incubation. Similar results was observes by Follett $e t$ al. [19]. From several studies it has been found that the addition of organic residues increases the soil organic carbon level initially and with the course of time organic carbon content decreases in soil up to a certain period [20] [21].

\section{4. $\mathrm{KCl}$ Extractable Soil $\mathrm{NH}_{4}^{+}-\mathrm{N}$ Content}

There was a slight release of $\mathrm{NH}_{4}^{+}-\mathrm{N}$ in all the manure treatments (Table 5). As expected the application of organic manures produced higher amount of available $\mathrm{NH}_{4}^{+}-\mathrm{N}$ in soils compared to control (no manure was added). The content of $\mathrm{NH}_{4}^{+}-\mathrm{N}$ released from control and cow dung amended soils differed significantly $(\mathrm{p}<$ 0.05 ) with time of different incubation. However, there was no significant difference in $\mathrm{NH}_{4}^{+}-\mathrm{N}$ contents among different incubation periods when either chicken manure alone or cow dung and chicken manure mixed in combination. After 60 days of incubation, the highest amount of $\mathrm{NH}_{4}^{+}-\mathrm{N}$ was found when cow dung and 
Table 5. $\mathrm{NH}_{4}^{+}-\mathrm{N}$ contents $\left(\mathrm{mg} \cdot \mathrm{kg}^{-1}\right)$ of soils at different periods of incubation.

\begin{tabular}{|c|c|c|c|c|}
\hline \multirow{2}{*}{ Treatments } & \multicolumn{4}{|c|}{ Periods of Incubation } \\
\hline & 15 days & 30 days & 45 days & 60 days \\
\hline Control & $89.79 b \pm 4.20$ & $92.21 b \pm 3.96$ & $111.63 \mathrm{a} \pm 4.20$ & $120.12 \mathrm{a} \pm 0.00$ \\
\hline $\mathrm{CD}\left(10 \mathrm{t} \cdot \mathrm{ha}^{-1}\right)$ & $103.13 b \pm 2.10$ & $107.99 b \pm 5.56$ & $129.83 a \pm 2.10$ & $133.47 a \pm 2.10$ \\
\hline CM (10 t $\left.\cdot h^{-1}\right)$ & $126.19 \mathrm{a} \pm 4.20$ & $129.83 a \pm 4.71$ & $131.04 \mathrm{a} \pm 3.64$ & $139.53 a \pm 5.56$ \\
\hline CD + CM (1:1) & $124.97 \mathrm{a} \pm 4.58$ & $127.40 \mathrm{a} \pm 3.64$ & $133.47 \mathrm{a} \pm 2.02$ & $141.96 a \pm 3.64$ \\
\hline
\end{tabular}

Means followed by the same letter(s) in a raw(s) do not differ significantly from each other at $5 \%$ level of significance.

chicken manure applied in conjunction (16.36\% over control) followed by chicken manure alone (16.16\% over control). The amount of $\mathrm{NH}_{4}^{+}-\mathrm{N}$ generated from control soil reached $33.78 \%$ of its initial value $\left(90 \mathrm{mg} \cdot \mathrm{kg}^{-1}\right.$ soil) after 60 days, whereas the value was $10.58 \%$ in case of chicken manure amended soil (125 $\left.\mathrm{mg} \cdot \mathrm{kg}^{-1} \mathrm{soil}\right)$. Significant positive relationship between $\mathrm{N}$ contents and incubation time indicates mineralization of the easily convertible compounds during the incubation period. The release of nutrients from organic manures and organic fertilizers depends on the types of manure, rates of application and moisture level. Rahman et al. [4] stated that the mineralization of nitrogen is influenced by incubation period, rate of organic materials application, moisture regime and type of soil. Our results showed higher amount of $\mathrm{N}$ increase with incubation time in manure amended soils compared with control soil. Similar results were also reported by other investigators [4] [14] [22]. Duffera [5] observed that processed swine lagoon solids increased the concentrations of $\mathrm{NH}_{4}^{+}-\mathrm{N}$ and during the first second weeks and by the second to fourth week after application, the $\mathrm{NH}_{4}^{+}-\mathrm{N}$ concentrations dropped.

\section{Conclusion}

From the study it can be concluded that addition of the three organic amendments decreased soil $\mathrm{pH}$ and increased electrical conductivity and soil $\mathrm{NH}_{4}^{+}-\mathrm{N}$ with incubation time. As $\mathrm{N}$ content increased with incubation in organic amended soils, this should be taken into consideration during crop production.

\section{References}

[1] Escobar, M.E.O. and Hue, N.V. (2008) Temporal Changes of Selected Chemical Properties in Three Manure Amended Soils of Hawaii. Bioresource Technology, 99, 8649-8654. http://dx.doi.org/10.1016/j.biortech.2008.04.069

[2] Hue, N.V., Craddock, G.R. and Adams, F. (1986) Effect of Organic Acids on Aluminum Toxicity in Subsoils. Soil Science Society of America Journal, 50, 28-34. http://dx.doi.org/10.2136/sssaj1986.03615995005000010006x

[3] Wong, M.T.F. and Swift, R.S. (2003) Role of Organic Matter in Alleviating Soil Acidity. In: Rengel, Z., Ed., Handbook of Soil Acidity, Marcel Dekker, Inc., New York, 337-358. http://dx.doi.org/10.1201/9780203912317.ch12

[4] Rahman, M.H., Islam, M.R., Jahiruddin, M., Puteh, A.B. and Mondal, M.M.A. (2013) Influence of Organic Matter on Nitrogen Mineralization Pattern in Soils under Different Moisture Regimes. International Journal of Agriculture and Biology, 15, 55-61.

[5] Duffera, M., Robarge, W.P. and Mikkelsen, R.L. (1999) Estimating the Availability of Nutrients from Processed Swine Lagoon Solids through Incubation Studies. Bioresource Technology, 70, 261-268. http://dx.doi.org/10.1016/S0960-8524(99)00039-5

[6] Edwards, D.R. and Daniel, T.C. (1992) Environmental Impacts of On-Farm Poultry Waste Disposal: A Review. Bioresource Technology, 41, 9-33. http://dx.doi.org/10.1016/0960-8524(92)90094-E

[7] Hao, X., Godlinski, F. and Chang, C. (2008) Distribution of Phosphorus Forms in Soil Following Long-Term Continuous and Discontinuous Cattle Manure Applications. Soil Science Society of America Journal, 72, 90-97. http://dx.doi.org/10.1016/0960-8524(92)90094-E

[8] Myint, A.K., Yamakawa, T., Kajihara, Y., Myint, K.K.M. and Zenmyo, T. (2010) Nitrogen Dynamics in a Paddy Field Fertilized with Mineral and Organic Nitrogen Sources. American-Eurasian Journal of Agricultural and Environmental Sciences, 7, 221-231.

[9] Weeraratna, C.S. (1979) Pattern of Nitrogen Release during Decomposition of Some Green Manures in a Tropical Alluvial Soil. Plant and Soil, 53, 287-294. http://dx.doi.org/10.1007/BF02277863

[10] Khalil, M.I., Van, C.O., Boeckn, P. and Rosenani, A.B. (2001) Nitrogen Transformation and Emission of Greenhouse Gases from Three Acid Soils of Humid Tropics Amended with N Sources and Moisture Regime. Communications in 
Soil Science and Plant Analysis, 32, 2893-2907. http://dx.doi.org/10.1081/CSS-120000970

[11] Pathak, H. and Sarkar, M.C. (1994) N Supplying Capacity of an Ustochrept Amended with Manures, Urea and Their Combinations. Journal of Indian Society of Soil Science, 42, 261-267.

[12] Huq, S.M.I. and Alam, M.D. (2005) A Handbook on Analyses of Soil, Plant, and Water. BACER-DU, University of Dhaka, Dhaka, 1-246.

[13] Parkinson, J.A. and Allen, S.E. (1975) A Wet Oxidation Procedure Suitable for the Determination of Nitrogen and Mineral Nutrients in Biological Materials. Communications in Soil Science and Plant Analysis, 6, 1-11. http://dx.doi.org/10.1080/00103627509366539

[14] Dikinya, O. and Mufwanzala, N. (2010) Chicken Manure-Enhanced Soil Fertility and Productivity: Effects of Application Rates. Journal of Soil Science and Environmental Management, 1, 46-54.

[15] Azeez, J.O. and Van Averbeke, W. (2012) Dynamics of Soil pH and Electrical Conductivity with the Application of Three Animal Manures. Communications in Soil Science and Plant Analysis, 43, 865-874. http://dx.doi.org/10.1080/00103627509366539

[16] Smith, J.L. and Doran, J.W. (1996) Measurement and Use of pH and Electrical Conductivity for Soil Quality Analysis. In: Doran, J.W and Jones, A.J., Eds., Methods For assessing Soil Quality, Soil Science Society of America Journal, SSSA, Madison, 49.

[17] De Neve, S., Van De Steene, J., Hartman, R. and Hofman, G. (2000) Using Time Domain Reflectometry for Monitoring Mineralization of Nitrogen from Soil Organic Matter. European Journal of Soil Science, 51, 295-304. http://dx.doi.org/10.1046/j.1365-2389.2000.00306.x

[18] Eigenberg, R.A., Doran, J.W., Nienaber, J.A., Ferguson, R.B. and Woodbury, B.L. (2002) Electrical Conductivity Monitoring of Soil Condition and Available N with Animal Manure and Cover Crop. Agriculture, Ecosystems \& Environment, 88, 183-193. http://dx.doi.org/10.1016/S0167-8809(01)00256-0

[19] Follett, R.F., Paul, E.A. and Pruessner, E.G. (2007) Soil Carbon Dynamics during a Long Term Incubation Study Involving ${ }^{13} \mathrm{C}$ and ${ }^{14} \mathrm{C}$ Measurements. Soil Science, 172, 189-208. http://dx.doi.org/10.1097/ss.0b013e31803403de

[20] Gulser, C., Demir, Z. and Serkan, I.C. (2010) Changes in Some Soil Properties at Different Incubation Periods after Tobacco Waste Application. Journal of Environmental Biology, 31, 671-674.

[21] Manivannan, S., Balamurugan, M., Parthasarathi, K., Gunasekaran, G. and Ranganathan, L.S. (2009) Effect of Vermicompost on Soil Fertility and Crop Productivity-Beans (Phaseolus vulgaris). Journal of Environmental Biology, 30, 275-281.

[22] Vel Murugan, A. and Swarnam, T.P. (2013) Nitrogen Release Pattern from Organic Manures Applied to an Acid Soil. Journal of Agricultural Science, 5, 74-184. 